\title{
KARAKTERISTIK SENSORI DAN FISIKO-KIMIA MIE BASAH DENGAN SUBSTITUSI DAGING IKAN CENDRO (Tylosurus crocodilus)
}

\author{
Characteristics of Sensory and Physico-Chemistry of Wet Noodles with Subtitution of Needle Fish Meat (Tylosurus \\ crocodilus)
}

\author{
Astri Rahayu ${ }^{1 *}$, Asnani ${ }^{1}$, Nur Asyik ${ }^{2}$ \\ 1Jurusan Teknologi Hasil Perikanan, Fakultas Perikanan dan Ilmu Kelautan Universitas Halu Oleo, Kendari, \\ Sulawesi Tenggara, Indonesia \\ 2Jurusan IImu dan Teknologi Pangan, Fakultas Pertanian Universitas Halu Oleo, Kendari, Sulawesi Tenggara, \\ Indonesia \\ *Email korespondensi: astrirazak@gmail.com (Telp: +6285216434249) \\ Diterima: 27 Juni/ Disetujui 20 Desember 2019
}

Cara sitasi: Rahayu A, Asnani, Asyik N. 2020. Karakteristik sensori dan fisiko-kimia mie basah dengan substitusi daging ikan cendro (Tylosurus crocodilus). Jurnal Fish Protech. 3(1):58-66.

\section{ABSTRACT}

The aims of this study was to determine the effect of substitution of Cendro fish meat on sensory properties (color, aroma, taste and texture physical properties (water absorption, and developmental power) and chemical properties (moisture content and protein content) in wet noodle This study used Completely Randomized Design (CRD) consisting of 4 treatments, namely M0 (Wheat flour 100\%), M1 (Wheat flour 95\%: Needle fish meat 5\%), M2 (Wheat flour 90\%: Needle fish meat 10\%), M3 (Wheat flour 85\%: Needle fish meat 15\%) that repeated for three times. Observed data were analyzed using ANOVA (Analysis of variance) at the $95 \%$ confidence level, $(P>0.05)$ and testing was carried out by the DMRT (Duncan Multiple Range Test) test. The results obtained showed that substitution of Needle fish meat on wet noodles had a very significant effect on sensory values, physical properties and chemical values of wet noodles. the best treatment sensory test was obtained in treatment M1 with a fairly good panelist assessment. The mean sensory color, aroma, taste, and texture with categories (likes). The physical properties of wet noodles absorption were highest in treatment MO (control) with a value of (60\%), the development of wet noodles was highest in treatment $\mathrm{MO}$ (control) with a value of $95 \%$. The chemical analysis of the highest moisture content in the M0 treatment (control) with a moisture content of (64.06\%) and the highest protein content in the M3 treatment was (12.29\%).

Keywords: wet noodles, needle fish meat, sensory test, physical test, chemical test

\begin{abstract}
ABSTRAK
Tujuan penelitian ini adalah untuk mengetahui pengaruh substitusi daging ikan cendro terhadap sifat sensori (warna, aroma, rasa, dan tekstur) sifat fisik (daya serap air, dan daya pengembangan) serta sifat kimia (kadar air dan kadar protein) pada mie basah. Penelitian ini menggunakan Rancangan Acak Lengkap (RAL) yang terdiri dari 4 perlakuan yaitu M0 (Tepung terigu 100\%), M1(Tepung terigu 95\% : daging ikan cendro 5\%), M2 (Tepung terigu 90\% : daging ikan cendro 10\%), M3 (Tepung terigu $85 \%$ : daging ikan cendro 15\%). dan diulang sebanyak tiga kali. Data hasil pengamatan dianalisis menggunakan ANOVA (Analysis of variance) pada taraf kepercayaan $95 \%$, $(P>0,05)$ dan uji lanjut dengan DMRT (Duncan Multiple Range Test). Hasil penelitian yang diperoleh menunjukkan bahwa substitusi daging ikan cendro terhadap mie basah memberikan pengaruh nyata terhadap nilai sensori, sifat fisik dan nilai kimia mie basah. Perlakuan terbaik uji sensori yang meliputi warna, aroma, rasa, dan tekstur diperoleh pada perlakuan M1 (Tepung terigu 95\% : daging ikan cendro 5\%), penilaian panelis yang cukup baik, dengan kategori (suka). Sifat fisik daya serap air mie basah tertinggi pada perlakuan M0 (Tepung terigu 100\%) dengan nilai sebesar (60\%), daya kembang mie basah tertinggi pada perlakuan M0 (kontrol) dengan nilai sebesar 95\%. Analisis kimia kadar air tertinggi pada perlakuan M0 (kontrol) dengan nilai kadar air sebesar $(64,06 \%)$ dan kadar protein tertinggi pada perlakuan M3 (Tepung terigu $85 \%$ : daging ikan cendro15\%) sebesar $(12,29 \%)$.
\end{abstract}

Kata kunci: analisis kimia, analisis sensori, analisis sifat fisik, mie basah, daging ikan cendro, 


\section{PENDAHULUAN}

Indonesia, memiliki potensi lestari (maximum sustainable yield) ikan laut seluruhnya 6,4 juta ton/tahun atau sekitar $7 \%$ dari total potensi lestari ikan laut dunia. dengan melihat luasnya perairan Indonesia serta potensi ikan yang ada di dalamnya, sungguh sektor bisnis dibidang ini sangat menjanjikan. Penemuan para ahli kesehatan dunia menyatakan bahwa ikan dan berbagai jenis seafood lainnya sangat baik bagi kesehatan dan kecerdasan manusia. Salah satu sumberdaya perikanan yang dihasilkan dari perairan Sulawesi Tenggara adalah ikan cendro (Tylosurus crocodilus) dan dikenal dengan nama lokal sebagai ikan sori. Menurut Tamarol, et al., (2012), Ikan cendro (Tylosurus crocodilus) merupakan ikan pelagis yang hidup dekat permukaan sekilas mirip barakuda, tetapi mulutnya lebih panjang dan lebih ramping, ukuran ikan ini dapat mencapai panjang 100 $\mathrm{cm}$ dan yang umum tertangkap $60-70 \mathrm{~cm}$.

Kekurangan energi protein (KEP) masih merupakan masalah utama dibidang kesehatan yang belum seluruhnya terpecahkan di Indonesia. KEP disebabkan oleh kurangnya asupan makanan yang tidak cukup mengandung energi dan protein. Pola komsumsi masyarakat Indonesia dalam pemenuhan kebutuhan protein masih bertumpu pada protein nabati. Konsumsi protein hewani untuk pemenuhan gizi masyarakat masih rendah. Subsektor perikanan memiliki potensi yang baik untuk berkontribusi didalam pemenuhan gizi masyarakat, khususnya protein hewani ikan dapat menjadi solusi untuk menanggulagi kasus defisiasi konsumsi protein di Indonesia dengan memanfaatkan daging ikan cendro (Tylosurus crocodilus) yang mengandung protein dalam pembuatan mie basah. ikan cendro mengandung protein relatif tinggi sebesar $13,26 \%$ (Dhaneesh et al., (2012).

Mie adalah salah satu produk pangan yang paling popular khususnya Asia Timur dan Asia Tenggara. di Indonesia mie merupakan makanan yang sangat digemari oleh anak-anak dan orang dewasa karena praktis. Frekuensi komsumsi mie yang tinggi berpeluang menimbulkan masalah dapat menurunkan devisa Negara karena bahan baku mie pada umumnya adalah tepung terigu (Auliah, 2012). Gandum (terigu) termasuk pangan dengan nilai impor yang tinggi dan tergolong pangan yang tidak diproduksi dalam negeri. Ketua Umum Asosiasi Produsen Tepung Terigu Indonesia (APTINDO), Franciscus Welirang, melaporkan bahwa komsumsi tepung terigu Indonesia pada tahun 2013 diperkirakan mencapai 5,43 juta ton, naik 7\% dari tahun 2012 yang mencapai 5,08 juta ton (Prihtiyani, 2013). Produk mie bukanlah merupakan makanan yang dianggap istimewa, hal ini terjadi karena umumnya kandungan gizi produk mie dan olahannya masih sangat rendah kandungan energi dan karbohidrat yang tinggi namun rendah pada kandungan protein. Rendahnya kandungan zat gizi tersebut maka perlu dilakukan modifikasi bahan dasar mie untuk memperkaya nilai gizinyayaitu dengan mensubstitusi bahan pangan lokal sebagai sumber protein hewani seperti ikan.

Substitusi daging ikan untuk pembuatan mie basah menurut (Murniyati dan Irma, 2010) daging ikan sebagai bahan dasar membuat mie sangat prospektif untuk dikembangkan, mengingat ikan adalah salah satu bahan makanan yang murah, banyak disukai oleh masyarakat Indonesia, memiliki cita rasa yang khas, tersedia melimpah dan kandungan gizinya relatif tinggihal inilah yang menjadi faktor pendorong untuk mengembangan produk-produk makanan yang berbasis ikan sebagai produk pangan yang bernilai gizi tinggi.

Salah satu upaya untuk meningkatkan kandungan gizi pada mie basah adalah dengan memanfaatkan daging ikan cendro (Tylosurus crocodilus) sebagai bahan baku utama pembuatan mie basah, diharapkan mampu meningkatkan kandungan protein serta menjadi nilai tambah pada produk mie basah. Saat ini penelitian tentang mie basah hanya dengan penambahan daging ikan belut (Monopterus albus zuieuw) (Candra dan Hafni, 2018) dan substitusi daging keong mas (Pomacea canaliculata) (Mualim, et al.,2013) belum adanya penelitian tentang pembuatan mie basah substitusi 
daging ikan cendro (Tylosurus crocodilus), oleh karena itu perlu dilakukan penelitian.

\section{Alat dan Bahan}

\section{METODE PENELITIAN}

Peralatan yang digunakan dalam penelitian ini adalah : baskom stainless, sarung tangan, panci stainless, kompor gas, perangkat pencetak mie, grinding, pisau, gelas ukur, thermometer, timbangan digital, timbangan analitik, Erlenmeyer, cawan, desikator, hot plate, spatula, pipet tetes, dan oven.

Bahan yang digunakan yaitu daging ikan cendro (Tylosurus crocodilus) tepung terigu, air, kuning telur, garam, soda kue. Bahan yang digunakan untuk analisis kimia adalah aquades, selenium, $\mathrm{H} 2 \mathrm{SO} 4, \mathrm{NaOH}$, kertas saring, dan larutan standar protein.

\section{Rancangan Penelitian}

Penelitian ini mengunakan metode rancangan acak lengkap (RAL) yang terdiri dari 4 taraf perlakuan dengan perbandingan penggunaan daging ikan cendro dan tepung terigu yaitu : $0 \%$ dan $100 \%$ (M0), $5 \%$ dan $95 \%$ (M1), $10 \%$ dan $90 \%$ (M2), $15 \%$ dan $85 \%$ (M3). Setiap perlakuan diulang sebanyak 3 kali sehingga produk mie basah substitusi daging ikan cendro diperoleh 12 unit percobaan

\section{Pembuatan Mie Basah \\ Penyiapan bahan Baku}

Persiapan daging ikan cendro, pada tahap awal bahan baku ikan cendro diperoleh dari TPI (Tempat Pelelangan Ikan) Sodoha Kendari selama transportasi dengan menggunakan es. Ikan cendro dicuci dengan air mengalir, kemudian disiyangi dan dipisahkan daging, kepala, tulang, dan kulit ikan, daging ikan dicuci, dipotong kecil-kecil, dipress menggunakan kain belacu, selanjutnya daging ikan dilumatkan, pelumatan daging ikan dilakukan menggunakan grinding sampai daging tergiling.

\section{Pengolahan Mie Basah}

Pada tahapan pembuatan mie basah substitusi daging ikan cendro lumat dan tepung terigu yaitu : $0 \%$ dan 100\% kontrol (M0), $5 \%$ dan $95 \%$ (M1), $10 \%$ dan $90 \%$ (M2), serta $15 \%$ dan $85 \%$ (M3). Dicampur semua bahan kedalam wadah pengadonan, selanjutnya $5 \%$ kuning telur yang telah dikocok kemudian adoni hingga tercampur rata. Aiir 38\% yang telah ditambahkan garam $(\mathrm{NaCl})$ sebanyak $2 \%$, masukkan ke dalam adonan, diadon hingga kalis, selama 15 menit ditandai dengan tidak lengketnya adonan dan juga kelihatan mengkilat, Adonan dipress dengan perangkat pencetak mi. lembaran mie diatur ketebalan 1-5 mm dipress lalu dicetak membentuk untaian mie dengan menggunakan perangkat pencetak mie (rool press) yang digunakan dengan tenaga tangan. Selanjutnya dimasukkan untaian mie ke dalam panci yang berisi air yang telah dididihkan sebanyak $1 \mathrm{~L}$ kemudian direbus selama 2 menit dengan suhu $100^{\circ} \mathrm{C}$. Mie basah hasil perebusan didinginkan dalam baskom plastik. Mie basah yang dihasilkan kemudian dianalisis sesuai dengan parameter yang diamati.

\section{Variabel Penelitian}

Variabel penelitian ini yaitu, Analisis sensori (warna, aroma, rasa dan tekstur.), analisis sifat fisik (daya serap air, dan pengembangan mie basah), analisis kimiai (kadar air, dan kadar protein)

\section{Analisis Data}

Data hasil penelitian sensori dianalisis menggunakan sidik ragam Anova. Jika terdapat perbedaan yang sangat nyata kemudian akan diuji lanjut menggunakan uji jarak berganda DMRT (Duncan Multiple Range Test) dengan taraf kepercayaan $95 \% \quad(a=0,05)$. Data diolah menggunakan aplikasi SAS.

\section{Analisis Sensori}

\section{HASIL DAN PEMBAHASAN}

Rekapitulasi hasil analisis ragam pada produk mie basah dengan disubstitusi daging ikan cendro terhadap nilai hedonik dan uji kadar air dan kadar protein dapat disajikan pada Tabel 1. 
Tabel 1. Rekapitulasi analisis ragam mie basah substitusi daging ikan cendro.

\begin{tabular}{lc}
\hline $\begin{array}{l}\text { No.Variabel } \\
\text { Pengamatan }\end{array}$ & Analisis Ragam \\
\hline 1. Uji hedonik warna & $*$ \\
2. Uji hedonik aroma & $*$ \\
3. Uji hedonik rasa & $*$ \\
4. Uji hedonik tekstur & $*$ \\
5. Kadar air & $* *$ \\
6. Kadar protein & $* *$
\end{tabular}

Keterangan :*= Berpengaruh nyata, ${ }^{* *}$ Berpengaruh sangat nyata.

Berdasarkan data pada Tabel 1 menunjukkan bahwa produk mie basah substitusi daging ikan cendro berpengaruh nyata terhadap uji hedonik warna, aroma, rasa, dan tekstur sedangkan uji kimia berpengaruh sangat nyata terhadap kadar air, dan kadar protein.

\section{Warna}

Hasil penilaian uji hedonik warna produk mie basah substitusi daging ikan cendro disajikan pada Tabel 2 .

Tabel 2. Rerata hasil penelitian uji hedonik warna mie basah

\begin{tabular}{|c|c|c|c|}
\hline Perlakuan & 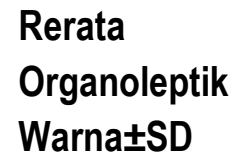 & Kategori & $\begin{array}{l}\text { DMRT } \\
0.05 \%\end{array}$ \\
\hline MO & $3.05^{b} \pm 0.90$ & $\begin{array}{l}\text { Agak } \\
\text { Suka }\end{array}$ & \\
\hline M1 & $3.57^{a} \pm 0.82$ & Suka & $2=0.31$ \\
\hline M2 & $3.14^{b} \pm 0.65$ & $\begin{array}{l}\text { Agak } \\
\text { Suka }\end{array}$ & $3=0.32$ \\
\hline M3 & $3.08^{b} \pm 0.74$ & $\begin{array}{l}\text { Agak } \\
\text { Suka }\end{array}$ & $4=0.33$ \\
\hline $\begin{array}{l}\text { Keterangan } \\
\text { huruf yang } \\
\text { berdasarka }\end{array}$ & $\begin{array}{l}\text { :Angka-angka } \\
\text { arbeda menunj } \\
\text { jii DMRT0 } 05 \text { t }\end{array}$ & $\begin{array}{l}\text { ang diikuti } \\
\text { kan beda }\end{array}$ & $\begin{array}{l}\text { oleh notas } \\
\text { yata } \\
\text { an } 95 \%\end{array}$ \\
\hline
\end{tabular}

Penilaian tertinggi hasil uji kesukaan terhadap warna diperoleh nilai rata-rata tertinggi pada perlakuan M1(Tepung terigu 95\% : daging ikan cendro $5 \%$ ) dengan nilai rata-rata 3.09\% (suka), hal ini diduga karena konsentrasi tepung terigu yang digunakan lebih banyak dari konsentrasi daging ikan cendro, sehingga warna mie yang dihasilkan lebih disukai panelis. Hal ini didukung penelitian Mualim et al., (2013) menyatakan bahwa penambahan tepung terigu selain fungsinya memperbaiki elastisitas, juga sebagai bahan pengisi, serta pengikat air juga memberikan warna pada produk akhir olahan pangan.

Penilaian terendah hasil uji kesukaan panelis terhadap warna mie basah diperoleh nilai rata-rata pada perlakuan M3 (Tepung terigu 85\% : tepung daging ikan 15\%) dengan nilai rata-rata 2.09 (agak suka). hal ini diduga karena seiring bertambahnya konsentrasi daging ikan cendro yang ditambahkan kedalam adonan mie basah maka nilai warna pada mie basah yang disubstitusi daging ikan cendro mengalami penurunan. Hal ini sejalan dengan penelitian Candra dan Hafni, (2018) yang menyatakan bahwa semakin banyak penambahan daging ikan membuat mie basah menjadi semakin gelap. Hal inilah yang menyebabkan kecerahan mie basah menurun. Kecerahan mie basah sendiri juga dipengaruhi oleh jumlah tepung terigu yang digunakan dalam pembuatan mi basah, dimana pada tepung terigu memiliki nilai derajat putih yang tinggi. Dalam jurnal Pasca Panen Widaningrum et al. (2005) nilai derajat putih untuk tepung terigu sebesar $87 \%$.

\section{Aroma}

Hasil penilaian uji hedonik aroma produk mie basah substitusi daging ikan cendro disajikan pada Tabel 3. 
Tabel 3. Rerata hasil penelitian uji hedonik aroma mie terhadap aroma mie basah yang dihasilkan. Hal ini basah. didukung dengan penelitian Silviana (2008),

Rerata

Organoleptik

Perlakuan Aroma \pm SD

\begin{tabular}{|c|c|c|c|}
\hline MO & $2.94^{\mathrm{ab}} \pm 0.74$ & $\begin{array}{l}\text { Agak } \\
\text { Suka }\end{array}$ & \\
\hline M1 & $3.50^{\mathrm{a}} \pm 0.77$ & Suka & $2=0.22$ \\
\hline M2 & $2.90^{\mathrm{ab}} \pm 0.72$ & $\begin{array}{l}\text { Agak } \\
\text { Suka }\end{array}$ & $3=0.23$ \\
\hline M3 & $2.77^{b} \pm 0.70$ & $\begin{array}{l}\text { Agak } \\
\text { Suka }\end{array}$ & $4=0.23$ \\
\hline
\end{tabular}

Keterangan : Angka-angka yang diikuti oleh notasi huruf yang berbeda menunjukkan beda nyata berdasarkan uji DMRT0,05

Penilaian uji organoleptik aroma oleh pengamatan panelis pada produk mie basah yang dihasilkan diperoleh nilai berkisar 2,77 (agak suka) hingga 3,50 (suka) menunjukkan bahwa perlakuan substitusi daging ikan cendro pada produk mie basah bepengaruh nyata, penilaian tertinggi hasil uji kesukaan panelis terhadap aroma tertinggi pada perlakuan M1 (Tepung terigu 95\% : daging ikan cendro $5 \%$ ) dengan nilai rata-rata 3,50 (suka), hal ini diduga karena konsentrasi ikan cendro yang digunakan sangat sedikit sehingga tidak tercium aroma ikan cendro. Hal ini sejalan dengan penelitian Candra dan Hafni, (2018) tentang penambahan daging belut pada produk mie basah menyatakan bahwa konsentrasi daging ikan sangat sedikit sekali apabila dibandingkan dengan konsentrasi tepung terigu yang digunakan. Kondisi ini menyebabkan aroma ikan tertutupi atau tersamarkan oleh aroma yang dihasilkan tepung terigu.

Penilaian terendah hasil uji kesukaan panelis terhadap aroma diperoleh pada perlakuan M3 (Tepung terigu $85 \%$ : daging ikan $15 \%$ ) dengan nilai rata-rata 2,77 (agak suka). Hal ini diduga karena daging ikan cendro yang digunakan dalam pembuatan mie basah memiliki aroma khas ikan (amis) sehingga semakin tinggi konsentrasi daging ikan cendro yang digunakan maka akan semakin rendah penerimaan panelis menyatakan bahwa Flavor khas ikan dikarakterisasi oleh komponen volatil hasil reaksi enzimatik dan komponen yang berasal dari tempat hidupnya. Komponen daging ikan berasal dari jenis asam-asam amino dan asam lemak tidak jenuh sehinnga lebih mudah menjadi tengik dan menghasilkan flavor khas (amis) (Jefri, 2010).

\section{Rasa}

Hasil penilaian uji hedonik rasa produk mie basah substitusi daging ikan cendro disajikan pada Tabel 4.

Tabel 4. Rerata hasil penelitian uji hedonik rasa mie basah

\begin{tabular}{|c|c|c|c|}
\hline \multirow[b]{3}{*}{ Perlakuan } & \multicolumn{3}{|l|}{ Rerata } \\
\hline & \multicolumn{2}{|l|}{ Organoleptik } & \multirow{2}{*}{$\begin{array}{l}\text { DMRT } \\
0.05 \%\end{array}$} \\
\hline & Rasa $\pm S D$ & Kategori & \\
\hline & & Agak & \\
\hline (M0) & $3.06^{\mathrm{ab}} \pm 0.89$ & suka & \\
\hline \multirow[t]{2}{*}{ (M1) } & $3.59^{\mathrm{a}} \pm 0.86$ & Suka & $2=0.27$ \\
\hline & & Agak & \\
\hline \multirow[t]{2}{*}{ (M2) } & $2.95^{b} \pm 0.81$ & Suka & $3=0.28$ \\
\hline & & Agak & \\
\hline (M3) & $2.88^{b} \pm 0.80$ & Suka & $4=0.29$ \\
\hline
\end{tabular}

Keterangan : Angka-angka yang diikuti oleh notasi huruf yangberbedamenunjukkan beda nyata berdasarkan uj DMRT0,05

Hasil penilaian uji organoleptik rasa oleh pengamatan panelis pada produk mie basah yang dihasilkan berkisar 2,88 (agak suka) hingga 3,59 (suka) menunjukkan bahwa perlakuan substitusi daging ikan cendro pada produk mie basah bepengaruh nyata. Penilaian tertinggi hasil uji kesukaan terhadap rasa diperoleh pada perlakuan M1 (Tepung terigu 95\% : daging ikan cendro 5\%) dengan nilai rata-rata 3.59 (suka) hal ini diduga karena disebabkan oleh kandungan protein yang terdapat pada mie, sehingga pada saat proses perebusan, protein akan terdenaturasi menjadi asam amino. Menurut Winarno (1997), salah satu asam amino yang dapat menimbulkan rasa yang lezat asam amino glutamat. Kandungan asam amino glutamat pada 
daging ikan cendro per 100 gram yaitu sebesar 1,84\% (Dhanees et al., 2012). Hal ini juga sesuai dengan penelitian yang dilakukan Candra dan Hafni, (2018) melaporkan bahwa konsentrasi daging ikan sangat sedikit sekali apabila dibandingkan dengan tepung terigu yang digunakan sehingga dapat menyebabkan rasa ikan tersamarkan oleh rasa dari tepung terigu terhadap mie basah yang dihasilkan.

Penilaian terendah diperoleh pada perlakuan M3 (Tepung terigu 85\% : daging ikan cendro 15\%) dengan nilai rata-rata 2,88 (agak suka), hal ini diduga karena konsentrasi daging ikan cendro yang digunakan pada pembuatan mie basah lebih banyak sehingga rasa ikan semakin meningkat. Hal ini didukumg dengan penelitian Dhanees et al., (2012) rasa ikan cendro disebabkan oleh adanya senyawa seperti asam lemak dan asam amino yang berperang dalam memberikan cita rasa.

\section{Tekstur}

Hasil penilaian uji hedonik tekstur produk mie basah substitusi daging ikan cendro disajikan pada Tabel 5 .

Tabel 5. Rerata hasil penelitian uji hedonik tekstur mie basah.

\begin{tabular}{llcc}
\hline & $\begin{array}{l}\text { Rerata } \\
\text { Organoleptik }\end{array}$ & DMRT \\
Perlakuan & $\begin{array}{l}\text { Tekstur } \pm S D \\
\text { M0 }\end{array}$ & Kategori & $\mathbf{0 . 0 5 \%}$ \\
\hline M1 & $3.19^{\mathrm{a}} \pm 0.93$ & Agak Suka & \\
M2 & $3.57^{\mathrm{a}} \pm 0.87$ & Suka & $2=0.26$ \\
M3 & $3.00^{\mathrm{b}} \pm 0.85$ & Agak Suka & $3=0.27$ \\
\hline
\end{tabular}

Keterangan : Angka-angka yang diikuti oleh notasi huruf yang berbeda menunjukkan beda nyata berdasarkan uj DMRT0,05

Hasil penilaian uji organoleptik tekstur oleh pengamatan panelis pada produk mie basah yang dihasilkan berkisar 2,82 (agak suka) hingga 3,57 (suka), menunjukkan bahwa perlakuan substitusi daging ikan cendro pada produk mie basah bepengaruh nyata.

Penilaian tertinggi diperoleh pada perlakuan M1 (Tepung terigu 95\% : daging ikan cendro 5\%) dengan nilai 3,57 (suka). Hal ini diduga tekstur pada mie basah substitusi daging ikan cendro dipengaruhi oleh aktomiosin pada protein dan gluten dari terigu. Hal ini sesuai peryataan Pribadie, (2011) dalam Mualim et al. (2013) bahwa protein aktomiosin dapat membentuk sifat kekenyalan. Serta menurut Kusnandar (2010), komponen terigu yaitu gliadin dan glutenin, dapat membentuk sifat elastis pada produk olahan pangan.

Penilaian terendah diperoleh pada perlakuan M3 (Tepung terigu 85\% : daging ikan cendro 15\%) dengan nilai rata-rata 2.82 (agak suka). Hal ini diduga semakin tinggi substitusi daging ikan cendro maka tekstur yang dihasilkan akan semakin rendah disukai oleh panelis. dimana penggunaan daging ikan dalam jumlah yang banyak akan menyebabkan tekstur produk mie basah menjadi tidak elastis. Terjadi penurunan nilai tekstur setelah substitusi daging ikan cendro $15 \%$. Hal ini sejalan dengan penelitian yang dilaporkan oleh Candra dan Hafni, (2018) menyatakan bahwa semakin tinggi penambahan daging ikan yang digunakan maka akan menyebabkan penurunan nilai tekstur.

\section{Analisis Fisik}

\section{Daya Serap Air}

Histogram rata-rata nilai uji daya serap air mie basah dengan substitusi daging ikan cendro disajikan pada Gambar 1.

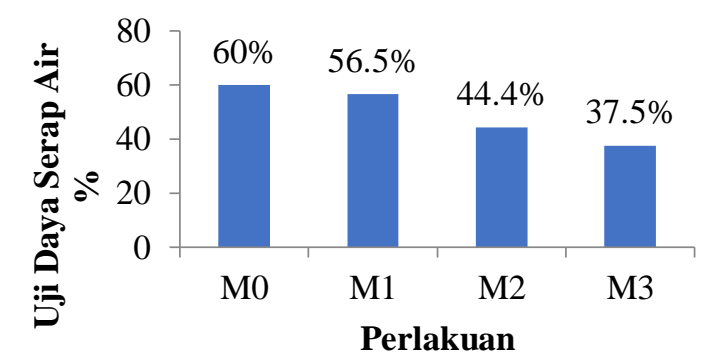

Gambar 1. Histogram nilai daya serap air mie basah Histogram daya serap air mie basah dengan substitusi daging ikan cendro diperoleh nilai rerata berkisar 37,5\% - 60\%. Nilai tertinggi daya serap air mie basah terdapat pada perlakuan M0 (kontrol) selisi nilai daya serap air mie basah dengan substitusi daging 
ikan cendro setiap perlakuan berkisar antara 3,5\%, $15,6 \%, 22,5 \%$.

Hasil pengukuran daya serap air mie basah penilaian tertinggi pada perlakuan MO (kontrol) konsentrasi (tepung terigu 100\% : daging ikan cendro $0 \%$ ) dengan nilai $60 \%$, hal ini diduga tingginya daya serap air pada mie basah dikarenakan sifat tepung terigu bersifat menyerap air. Hal ini didukung oleh penelitian Safriani (2013), tepung terigu mengandung protein dalam bentuk gluten yang sifatnya mudah dicampur dan daya serap airnya tinggi dan elastis.

\section{Pengembangan Mie Basah}

Histogram rata-rata nilai uji pengembanga mie basah dengan substitusi daging ikan cendro disajikan pada Gambar 2.

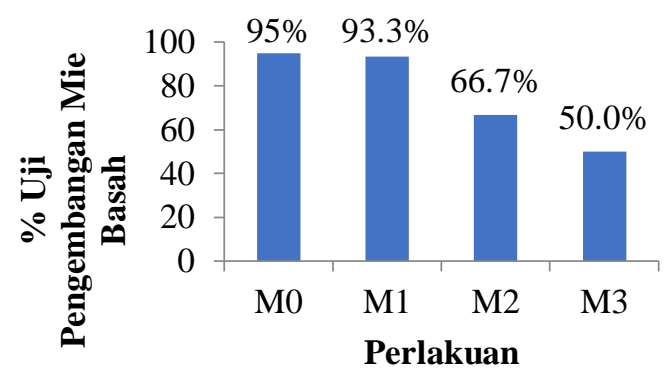

Gambar 2. Histogram nilai pengembangan mie basah

Histogram daya kembang mie basah dengan substitusi daging ikan cendro diperoleh nilai berkisar $50 \%-95 \%$. Nilai tertinggi daya kembang mie basah terdapat pada perlakuan MO (kontrol) selisi nilai daya kembang mie basah substitusi daging ikan cendro setiap perlakuan berkisar antara 1,7\%, 28,3\%, $45 \%$.

Hasil pengukuran daya kembang mie basah dengan substitusi daging ikan cendro penilaian tertinggi diperoleh pada perlakuan MO (kontrol) (tepung terigu $100 \%$ : daging ikan $0 \%$ ) dengan nilai $95 \%$, hal ini diduga semakin banyak daya kembang menyebabkan semakin banyak air yang diserap selama pemasakan. Hal ini didukung penelitian Merdiyanti, (2008) bahwa Daya pengembangan mie dipengaruhi tinggi rendahnya daya serap air mie, semakin tinggi nilai daya serap air, maka air yang diserap oleh mie akan semakin banyak yang mengakibatkan mie menjadi semakin mengembang.

\section{Analisis Kimia}

\section{Kadar Air}

Histogram rata-rata nilai uji kadar air mie basah dengan substitusi daging ikan cendro disajikan pada Gambar 3.

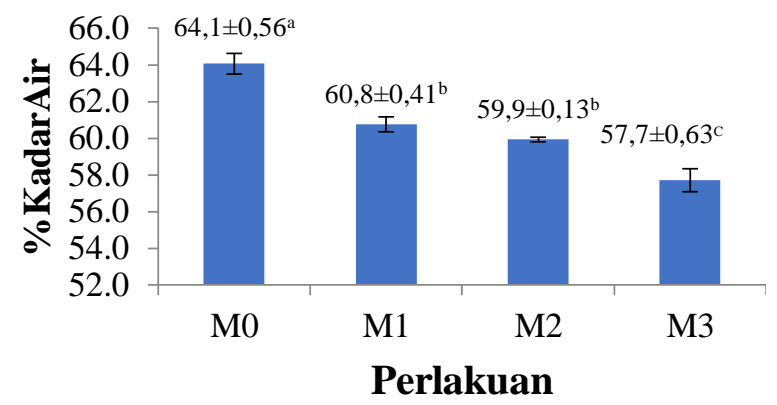

Gambar 3. Histogram nilai rata-rata kadar air mie basah dengan substitusi daging ikan cendro.

Keterangan : Angka-angka yang diikuti oleh notasi huruf yang berbeda menunjukkan beda nyata berdasarkan uji DMRT0,05 taraf kepercayaan $95 \%$.

Hasil analisis ragam menunjukkan bahwa substitusi daging ikan cendro dapat menurunkan kadar air mie basah pada perlakuan M0 (tepung terigu 100\% : daging ikan cendro $0 \%$ ) terhadap M1 (tepung terigu $95 \%$ : daging ikan cendro 5\%) M3 (tepung terigu $100 \%$ : daging ikan cendro $15 \%$ ) menurun yaitu $3,3 \%$ dan $6,35 \%$.

Kadar air tertinggi diperoleh pada perlakuan MO (kontrol) dengan konsentrasi (tepung terigu 100\% : daging ikan cendro $0 \%$ ) adalah sebesar $64,06 \%$, hal ini diduga karena penggunaan tepung terigu yang banyak tanpa substitusi daging ikan cendro pada produk mie basah. Hal ini didukung oleh penelitian Safriani (2013), menyatakan bahwa tepung terigu mengandung protein dalam bentuk gluten, sehingga sifatnya mudah dicampur, dan daya serap airnya tinggi dan elastis.

Kadar air terendah pada perlakuan M3 dengan konsentrasi (tepung terigu $85 \%$ : daging ikan cendro $15 \%$ ) sebesar $57,70 \%$, hal ini diduga semakin besar konsentrasi substitusi daging ikan cendro dapat mempengaruhi penurunan kadar air mie basah. Hal ini didukung penelitian Candra dan Hafni, (2018) meningkatnya protein dapat menyebabkan air sulit masuk kedalam granula pati tepung sehingga waktu gelanitisasi menjadi lama. Daging ikan cendro dalam 
mie basah mengandung protein, saat pemanasan mengalami denaturasi protein, menyebabkan pati sulit berikatan dengan air. Protein bersifat menghalangi penyerapan air didalam granula pati (Purnomo 1995).

\section{Kadar Protein}

Histogram rata-rata nilai uji kadar protein mie basah dengan substitusi daging ikan cendro disajikan pada Gambar 4.

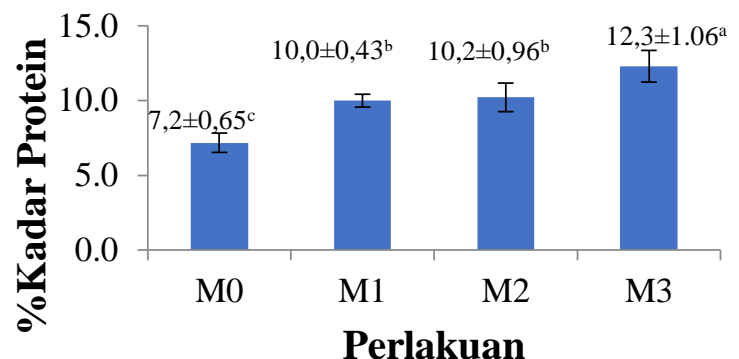

Gambar 4. Histogram nilai rata-rata kadar protein mie basah dengan substitusi daging ikan cendro.

Keterangan : Angka-angka yang diikuti oleh notasi huruf yang berbeda menunjukkan beda nyata berdasarkan uji DMRT0,05.

Hasil analisis ragam menunjukkan bahwa substitusi daging ikan cendro dapat meningkatkan kadar protein mie basah pada perlakuan M0 (tepung terigu $100 \%$ ), terhadap M1 (tepung terigu $95 \%$ : daging ikan cendro 5\%) dan M3(tepung terigu 85\% : daging ikan cendro $15 \%$ ) meningkat yaitu $5,12 \%$, dan $2,3 \%$.

\section{DAFTAR PUSTAKA}

[AOAC] Association of Official Analytical Communities. 2005. Official Methods of Analysis of AOAC International. Ed ke-18, Rev ke-2. Maryland (US): AOAC International.

Bilina, A., Waluyo, S., dan Suhandy, D. 2013. Kajian Sifat Fisik Mie Basah Dengan Penambahan Rumput Laut. JurnalTeknik Pertanian Lampung 4 (2) : 109-116.

Candra \& Hafni. R., 2018. Peningkatan Kandungan Protein Mie Basah dengan Substitusi Daging Ikan Belut (Monepturus abus zuieuw). Jurnal Teknik Lingkungan, 4(1) : 82-86, 2018.
Peningkatan kadar protein mie basah dengan substitusi daging ikan cendro diduga karena hilangnya kandungan karbohidrat dan air pada saat pengolahan mie. Hal ini sesuai dengan peryataan Mulyono (1976), karbohidrat sering kali bergabung dengan senyawa lain seperti protein yang disebut glikoprotein dan juga peryataan Pratama (2014), tinggi atau rendahnya protein yang terukur dipengaruhi oleh besarnya kandungan air yang hilang dari bahan, nilai protein yang terukur akan semakin besar.

\section{KESIMPULAN}

Berdasarkan penelitian yang telah dilakukan dapat disimpulkan sebagai berikut :

1. Substitusi daging ikan cendro menunjukkan pengaruh nyata terhadap nilai organoleptik warna, aroma, rasa, dan tekstur produk mie basah pada perlakuan M1 (Tepung terigu $95 \%$ : daging ikan cendro $5 \%$ ).

2. Nilai daya serap air tertinggi sebesar $60 \%$ dan nilai daya kembang mie basah tertinggi sebesar 95\% diperoleh pada perlakuan MO (kontrol) (tepung terigu $100 \%$ : daging ikan cendro $0 \%$ ).

3. Substitusi daging ikan cendro sebanyak $5-15 \%$ menunjukkan pengaruh nyata terhadap kandungan protein pada produk mie basah dengan kisaran kandungan protein sebesar $7,2 \%$ sampaii $12,3 \%$.

Dhaneesh KV, Noushad KM, Ajith Kumar TT. 2012. Nutrition Evaluation of Commercially Important Fish Species of Lakshadweep Archipelago. India. PLos ONE 7(9): e45439. Doi:10.1371/journal.pone.0045439.

Jefri. 2010. Alasan Ikan Amis. Tersedia dihttp://eksplorasi-dumia.blospot.com/html. (diakses 10 mei 2019).

Kusnandar, F. 2010. Kimia Pangan Komponen Makro.

PT. Dian Rakyat. Jakarta.

Merdiyanti, A. 2008. Paket Teknologi Pembuatan Mie Kering dengan Memanfaatkan Bahan Baku Tepung Jagung. Skripsi. Fakultas Teknologi Pertanian. IPB. Bogor. 
Mualim A.,Susi L,Siti H.R.J. 2013. Kandungan Gizi dan Karakteristik Mie Basah dengan Substitusi Daging Keog Mas (Pomacea Canaliculata). Jurnal Fistech, Vol II, No 01, 7482.

Murniyati, S., dan Irma H. 2010. Pengolahan Mie yang Difortifikasi Ikan dan Rumput Laut sebagai Sumber Protein, Serat Kasar, dan lodium. Jurnal Bioteknologi Kelautan dan Perikanan V (1).

Mulyono. 1976. Petunjuk Praktikum Biokimia. Yogyakarta: Universitas Gadjah Mada.

Nakai, S., dan Modler, H.W. 2000. Food Proteins Processing Applications. Toronto : Wiley$\mathrm{VCH}$.

Pratama RI. 2014. Karakteristik biskuit dengan penambahan tepung tulang ikan jangilus. Jurnal Akuatik 5(1):30-39.

Pomeranz, Y., dan Meloan, C.E. 1971. Food Analisysis: Theori and Practice. The AVI Publishing Co., Inc., Westport, Connecticut.

Purwani EY, Setiawaty Y, Setianto H, Widaningrum. 2006a. Characteristics and case study of sago noodle's acceptability in south sulawesi. Majalah IImu dan Teknologi Pertanian. 16(1): 24-33.

Purnomo., 1995. Aktivitas Air dan Peranannya dalam Pengawetan Pangan. Universitas Indonesia. Jakarta.
Pribadie, A,I. 2011. Kandungan gizi dan karakteristik mi basah dengan subtitusi daging ikan lele dumbo (Clarias gariepinus). Skripsi. Indralaya, Fakultas Pertanian, Universitas Sriwijaya.

Prihtiyani E. 2013. Konsumsi terigu tumbuh tujuh persen [internet]. [diakses pada 14 April 2019]. Tersedia dari: http://bisniskeuangan.kompas.com/.

Silviana.2008.Karakteristik/Flavor/Seafood/Segar.(onl ine).(http://www.foodreview.biz. (diakses 2 Mei 2019).

Tamarol J, Luasunaung A,dan Budiman J. 2012, Dampak Perikanan Tangkap Terhadap Sumberdaya Ikan dan Habitatnya di Perairan Pantai Terbukan Tengah Kepulauan Sangihe. Jurnal Perikanan dan Kelautan Tropis. 8(1):12- 16 .

Widyaningsih., Tri,dan D.,Murtini, E.S. 2006. Alternatif Pengganti Formalin PadaProduk Pangan. Trubus Agrisarana. Jakarta.

Widianingrum., Widowati, S., Soekarto, S.T. 2005. Pengkayaan Tepung Kedelai pada pembuatan Mie Basah dengan Bahan Baku Tepung Terigu yang disubstitusi Tepung Garut. Jurnal Institut Pertanian Bogor.2(1) 2005: 41-48.

Winarno FG. 1997. Kimia Pangan dan Gizi. Jakarta: P.T Gramedia Pustaka Utama. 